sive, because it's human insulin. They are going to produce it cheap. That is a very very powerful force behind the scenes, but it penetrates the scientific deliberations. So that in the United States we have scientists who in their public statements say "I'm only interested in the increase of human knowledge", while at the same time they have engaged lawyers to dissociate themselves from NIH funding, and get private funding, so that they can take out the patents.

Now we don't have a law in the United States that keeps anybody from introducing any gene into an epidemic strain of $E$. coli or salmonella or Shigella; and there are forces in that direction because of patents. If somebody else has a patent on making insulin in $E$. coli and you recognise that market what do you do? Take two of the venture capital corporations in the United States, Genentech and Cetus Corporation, both in California; the one has backing from International Nickel and the other from Standard Oil of Indiana. Their front men may be research scientists who say "we are only interested in the expansion of human knowledge", but the background there is very different.

\title{
ASTMS plans to radicalise university and health service research
}

\section{Sheila McKechnie talks to Robert Walgate}

The Association of Scientific, Technical, and Managerial Staffs (ASTMS), which called a meeting on genetic engineering last Friday, has its eye on health and safety in university laboratories. Laboratories in the health service are not left out either. "Freedom of research," says ASTMS health and safety officer Sheila McKechnie, "means whatever anybody wants it to mean at the time. And in the academic context it means that academics don't want to accept either social criteria for their decisions or an input from trades unions.

"If we've got standards of safety in GMAG laboratories it does seem to us that we should use GMAG as a comparison for work with dangerous pathogens; and if that is causing confusion in certain people's minds, then that's unfortunate, but when you talk about laboratory control and labora- tory safety we are looking to the GMAG model of containment for lots of other areas.

"You've got to remember that prior to 1974 [the date of enactment of the Health and Safety at Work Act] there were no legal standards which applied to the vast number of laboratories in which our members work-which is private research laboratories, public research laboratories, university laboratories, and National Health Service laboratories. Now you might say it's a very weak trade union argument to say that when you get a law you start doing something about it; but in fact it's a pattern of a great deal of trade union activity that when you get a law which protects in a minimum way the trade union movement, which hasn't previously seen it as an area for bargaining to be done in, sees a new impetus and sees the law as a minimum and begins to negotiate in that field.

"Laboratories in industry are more hygenic than the university or hospital laboratories. There's not the kind of scrimping on safety equipment that there is in a lot of hospital laboratories. They are probably more aware of their economic liability if anything goes wrong.

"The problem is the decision-making structure for the allocation of safety money. If unions like ASTMS push for grants from central government to improve laboratories, we would also want some control over how that money was spent. And there is almost total resistance to ASTMS having any say in both the amount and the allocation of that money. The problem in the universities is the anachronistic authority structure within those institutions; heads of departments in universities really are the last bastion of unilateral management prerogative. That is not the way that private companies work any more: they've been forced to recognise trades unions and work with them."
'REcombinant DNA' means different things to different people. Although it is now almost universally associated with the techniques of in vitro genetic manipulation, confusion can still arise when the term is loosely applied. (As in some comments on the cause of the recent case of smallpox in Birmingham.) For the products of 'old-fashioned' recombinationthe natural reshuffing of genes to produce bacteria, viruses, animals and men with a novel genetic make-up-are also recombinant DNAs.

So far there a few statutory controls on work with natural recombinants, even when it involves bacteria and viruses that can cause disease in man. But each experiment in which a recombinant organism is produced using the in vitro techniques of gene manipulation developed by molecular biologists come under the scrutiny of the Genetic Manipulation Advisory Group whose recommendations about the conditions in which the experiment should be carried out, are legally backed up by the Health and Safety Executive.

This has led to the paradox that experiments arriving at the same end-product can be carried out freely when the end is to be accomplished by natural recombination but come under scrutiny when in vitro recombinant techniques are to be used, and emphasises the difficulties in pro-

\section{Recombination: old and new}

ducing a logical and consistent set of guidelines for work in vitro recombinant DNAs.

Recombinant bacteria can arise naturally in a variety of different ways:

- Certain bacteria directly exchange their chromosomal DNA with members of their own species or with close relatives.

- Infection with particular bacterial viruses which can pick up pieces of bacterial DNA and pass these on to the next bacterium they infect can also produce a recombinant organism.

- Infection with certain bacterial viruses itself can dramatically change the nature of some bacteria. The ability to produce lethal toxins such as botulinum toxin and diphtheria toxin is conferred on the appropriate bacteria by infection with bacterial viruses which become integrated into the bacterial chromosome.

- Plasmids which can be transferred between quite distantly related bacterial species can transmit the genes for antibiotic resistance.

- Viruses can also exchange genetic material between similar or closely related types. Hybrid trains of influenza virus, herpes and smallpox, for example, all arise naturally from mixed infections or in mixed laboratory cultures of two or more different strains.

So-called 'in vitro recombinant DNA work' or 'genetic manipulation', specifically deals with work in which DNA from one organism is deliberately extracted, chopped up into manageable fragments with restriction enzymes and the resulting fragments spliced enzymatically into an appropriate plasmid or virus. This can then be introduced into the required recipient cell, whether bacterial, ycast or mammalian cell. The techniques of the molecular biologist can produce organisms that could have arisen naturally, but in addition they can also produce combinations that could not have arisen naturally. However, all in vitro recombinant experiments, whatever their outcome, are subject to GMAG controls in the UK and to the NIH guidelines in the USA.

A further twist to the story was provided earlier this year when American molecular biologists showed that in certain conditions, bacteria were quite capable of carrying out the 'in vitro' techniques themselves, using their own restriction enzymes to cut and splice foreign DNA into their own genetic material.

Eleanor Lawrence 